\title{
Nutrient Composition of Raw, Dry-Roasted, and Skin-On Cashew Nuts
}

\author{
L. E. Griffin ${ }^{2} \&$ L. L. Dean ${ }^{2}$ \\ ${ }^{1}$ Department of Food, Bioprocessing, and Nutrition Science, North Carolina State University, Raleigh, NC \\ 27695-7624, USA \\ ${ }^{2}$ USDA-ARS Market Quality and Handling Research Unit, United States Department of Agriculture, \\ Agricultural Research Service, Southeast Area, Box 7624, Raleigh, NC 27695-7624, USA \\ Correspondence: L. L. Dean, USDA-ARS Market Quality and Handling Research Unit, United States \\ Department of Agriculture, Agricultural Research Service, Southeast Area, Box 7624, Raleigh, NC 27695-7624, \\ USA. E-mail: lisa.dean@usda.ars.gov
}

Received: August 26, 2017

Accepted: September 9, 2017 Online Published: September 26, 2017

doi:10.5539/jfr.v6n6p13

URL: https://doi.org/10.5539/jfr.v6n6p13

\begin{abstract}
Cashew nuts are the second most popular tree nut in the US with sales growing at a rate of $7 \%$ per annum. The highest quality cashew nuts are traditionally whole, oil-roasted, and devoid of skins. The development of a technique to remove the caustic cashew nut shell liquid from cashews and leave the skins intact allows for the production of novel cashew products including skin-on or "wrapped" in addition to raw and dry roasted products. This study investigated the nutritional characteristics of these newer cashew products. These products were found to contain bioactive compounds including mono- and poly-unsaturated fatty acids, phytosterols, arginine, magnesium, tocopherols, and phenolic compounds. All the types of cashews exhibited higher levels of phytosterols than the amounts reported for other tree nuts. The skin-on cashews had higher levels of phenolic compounds compared to the other cashew varieties tested, indicating additional health benefits of consuming cashew nuts with skins.
\end{abstract}

Keywords: cashew, Anacardium occidentale L., nutrition, nut skins, analysis, CNSL

\section{Introduction}

\subsection{Cashew Industry}

The cashew tree (Anacardium occidentale L.) thrives in tropical climates within $27^{\circ}$ North and $28^{\circ}$ South of the equator (Akinhanmi, Atasie, \& Akintokun, 2008; Maia, Andrade, \& Zoghbi, 2000; Salam \& Peter, 2010). The trees are a resilient species that can tolerate drought and nutrient-deficient soil, and as such, are predominantly allowed to grow uncultivated and self-propagate, leading to high variability within the species (Akinhanmi et al., 2008; Azam-Ali \& Judge, 2001).

Cashew trees produce a fruit know as cashew apples and the cashew nuts are attached to the bottom of the fruit encased in a hard shell. One cashew nut is attached to the bottom of each apple. The fruits contain juice, but the flesh is very fibrous, thus they are used for secondary products such as wine, jam, juice, and vinegar with the nut being the more economically important product (Assuncao \& Mercadante, 2003; Salam \& Peter, 2010).

The processing and exportation of the cashew crop began in the 1950s and consumption has steadily increased (Martin, et al., 1997). In 2014, 630 thousand metric tons of cashew nuts were produced. India (164,286 metric tons), Vietnam (119,048 metric tons), and the Ivory Coast (109,583 metric tons) are the production leaders (Rico, Bullo, \& Salas-Salvado, 2015). The cashew is ranked as the second most expensive nut traded in the United States, after macadamia nuts.

\subsection{Cashew Processing}

Within the shell of the cashew is a porous honeycomb like structure containing a caustic fluid known as cashew nut shell liquid (CNSL) which surrounds the nut. The liquid is mainly composed of anacardic acid which is chemically similar to urushiol, found in poison ivy. It serves to protect the nut from insect attack during growth. It is removed from the nuts during processing, but can be used in other industrial applications such as paint, 
adhesives, and brake linings (Akinhanmi et al., 2008; FDA, 2013; Gedam \& Sampathkumaran, 1986; Teuber, Sathe, Peterson, \& Roux, 2002). Due to the toxic and corrosive nature of CSNL, cashews are not readily available in the shell for retail sale.

The processing of cashew nuts is labor intensive due to the hardness of the shells and the presence of CNSL. Processing is mostly performed manually and is the livelihood for thousands of families in developing countries (Rico et al., 2015). The shells are soaked in water to prevent scorching during drying and facilitate the removal of the shells. After drying, the shells become brittle and are easily removed. To remove the CNSL, a water washing technique is used. The nuts are dried and the testa are removed so that the nuts can be roasted in oil or air (Azam-Ali \& Judge, 2001; Salam \& Peter, 2010). The highest quality cashews are those that are whole, white, and devoid of testa (Hebbar \& Ramesh, 2005).

\subsection{Cashew Testa}

Cashew testa consist of 24-26\% tannins on average, which, when consumed, can cause astringent and tingling sensations in the mouth. For this reason, cashew testa are viewed as defects and therefore are typically removed during nut processing. Currently, the testa are sold to the leather industry (Nair, 2003; Salam \& Peter, 2010). Recent studies have indicated that cashew testa have high concentrations of water soluble phenolic compounds that have the ability to scavenge superoxide radicals, prevent the formation of hydroxyl radicals, and chelate metals. It is possible that consumption of cashew testa could produce beneficial in vivo effects (Kamath \& Rajini, 2007).

\subsection{Nutrition of Unique Cashew Products}

Nutritional information about oil roasted cashew nuts has been published (USDA, 2014). Given the recent development of novel cashew products (raw, dry-roasted, wrapped/skin-on), a nutritional analysis of the products was performed. This study adds to the current knowledge of cashew nutrition and reports the effects of the different processing techniques.

\section{Materials and Methods}

\subsection{Raw Materials and Sample Preparation}

Commercially manufactured cashew products (raw, dry-roasted, dry-roasted and wrapped) were obtained from the processor (Wenders Foods, Kerala, India). A composite sample of each product type was prepared by homogenizing 12 retail units ( $12 \mathrm{oz}$. cans). The composite samples were stored at $4^{\circ} \mathrm{C}$ in glass jars. Subsequent analyses were performed in triplicate or better from the composite homologous samples.

For the analyses of the lipid components, the oil was expressed from the sample homogenates using a hydraulic laboratory press (Carver, Inc., Wabash, IN) and stored at $-80^{\circ} \mathrm{C}$. The remaining cashew meal was pulverized, passed through a sieve, and collected in a cellulose thimble. The thimbles were inserted into a Soxhlet apparatus and the remaining lipids were extracted continuously with hexane for 6 hours. The defatted samples were then dried and stored at $-80^{\circ} \mathrm{C}$ until analysed.

\subsection{Reagents and Solutions}

The reagents used were ACS reagent grade and the solvents were Opitma grade and all were purchased from Thermo Fisher Scientific (Fair Lawn, NJ) unless otherwise noted. The deionized water was purified using an Elga type 1 ion exchange system (Elga Veolia, Woodridge, IL). The boron trifluoride, $5 \alpha$ cholestane, pyridine, myo-inositol, glucose, fructose, lactose, sucrose, cellobiose, raffinose, stachyose, sodium metabisulfite, octanol, nicotinic acid. $\alpha, \gamma, \delta$-tocopherols, Vitamin $\mathrm{K}_{1}$, Vitamin $\mathrm{K}_{2}, \beta$-carotene, Folin-Ciocalteau reagent, gallic acid, catechin, epicatichin, 2,2-diphenyl-1-picrylhydrazyl (DPPH), Trolox, and

2,2'-azobis(2-amidinopropane) dihydrochloride (AAPH) were purchased from Sigma-Aldrich (St. Louis, MO). The fatty acid methyl ester, phytosterol, phospholipid and $\beta$-tocopherol standards were purchased from Matreya, LLC (Pleasant Gap, PA). The BSTFA-Regisil@ (Bis(trimethylsilyl)trifluoroacetamide)) was purchased from Regis Technologies (Grove, IL). Standards of phosphatidylcholine, phosphatidylserine, phosphatidylethanolamine, and sphingomyelin were purchased from Avanti Polar Lipids (Alabaster, AL). Tryptophan was purchased from Pierce Chemical Corp. (Rockford, IL), procyanidin A2 was purchased from ChromaDex (Irvine, CA), the procyanidin trimer and procyanidin tetramer were purchased from Planta Analytica (Danbury, CT). Fluorescein was purchased from Riedel De Haen (Hanover, Germany).

\subsection{Proximate Analyses}

The cashews were analysed for moisture, total lipid, and total protein. The moisture was analysed using whole nuts according to the method outlined in Young et al. (1982). The nut samples $(n=4)$ were dried for 6 hours in a 
forced draft oven set at $130^{\circ} \mathrm{C}$. Total oil was measured using whole nuts $(\mathrm{n}=3)$ with a Minispec MQ One Seed Analyzer (Bruker Corporation, Billerica, MA) calibrated according to manufacturer specifications. Total protein was measured using a CEM Sprint Protein Analyzer (Matthews, NC). The whole cashew homogenates $(\mathrm{n}=5)$ were used to analyze protein according to the manufactures specifications.

\subsection{Determination of Amino Acid Profiles}

The samples $(\mathrm{n}=3)$ were prepared for amino acid analysis by the procedure outlined in Hagen, Frost, \&Augustin (1989). Performic acid oxidation was performed on the defatted cashew flour to protect cysteine and methionine from degradation during the analysis of amino acids. $0.1 \mathrm{~g}$ aliquots of the defatted samples were combined with $5 \mathrm{~mL}$ of chilled performic acid $\left(30 \% \mathrm{H}_{2} \mathrm{O}_{2}: 88 \%\right.$ formic acid $\left.1: 9 \mathrm{v} / \mathrm{v}\right)$, held on ice for 16 hours and quenched with $0.84 \mathrm{~g}$ of sodium metabisulfite. Excess solvent was evaporated using a Savant SpeedVac (Savant, Osterville, MA) for 2 hours. Digestion of the amino acids was then performed by adding $4 \mathrm{~mL}$ of $6 \mathrm{~N} \mathrm{HCl}$ with $1 \%$ phenol to the samples and heating at $120^{\circ} \mathrm{C}$ for 24 hours. Samples were cooled, then diluted to $25 \mathrm{~mL}$ with $0.02 \mathrm{~N} \mathrm{HCl}$ and filtered using $0.2 \mu$ Nylon syringe filters (Millex-HN, Millipore Corp., Billerica, MA).) The samples were analysed using a Hitachi Model L-8900 Amino Acid Analyzer (Hitachi High Technologies, Dallas, TX) with the conditions outlined in the instrument manual.

Tryptophan analysis was performed separately in accordance to the method of Kuminek et al. (2011). Defatted cashew flour was combined with $2 \mathrm{~mL}$ of $4.2 \mathrm{~N}$ sodium hydroxide in water, $50 \mathrm{mg}$ of dried hydrolyzed starch, and 1 drop of octanol. The samples were digested using a CEM Discover Hydrolyzer (CEM, Matthews, NC). Once the samples cooled to room temperature, $1.4 \mathrm{~mL}$ of $6 \mathrm{~N} \mathrm{HCl}$ and $5 \mathrm{~mL}$ of $95 \%$ ethanol was added and the samples were diluted to $25 \mathrm{~mL}$ using $0.2 \mathrm{M}$ phosphate buffer ( $\mathrm{pH}$ 7). The samples were filtered through $0.2 \mu$ syringe filters as for the acid hydrolyzed samples and analyzed on a Thermo Finnigan HPLC (Thermo Quest, San Jose, CA) fitted with a Lichrosorb C18 column ( 250 x $4.6 \mathrm{~mm}, 5 \mu \mathrm{m}$, Alltech Associates, Deerfield, IL). The mobile phase was $90 \% 0.02 \mathrm{M}$ phosphate buffer at $\mathrm{pH} 3.3$ in acetonitrile. UV detection at $280 \mathrm{~nm}$ was used. Tryptophan was quantified using an external standard curve from an authentic tryptophan standard (Pierce Chemical Corp., Rockford, IL).

\subsection{Determination of Fatty Acid Profiles}

Fatty acids were determined by GC using expressed cashew oil $(\mathrm{n}=3)$ as fatty acid methyl esters in accordance with the method outlined in Bannon et al. (1982). Analysis of the methyl esters was performed using a Perkin Elmer (Shelton, CT) Autosampler XL gas chromatograph fitted with a BPX70 (SGE Analytical Science, Austin, TX) capillary column ( $30 \mathrm{~m}$ length, $0.25 \mathrm{~mm}$ i.d., $0.25 \mu \mathrm{m}$ film thickness). The injector was a split, packed type set at $220^{\circ} \mathrm{C}$ with a split flow ratio of $40: 1(76.9 \mathrm{~mL} / \mathrm{min})$. The carrier gas was helium at $20 \mathrm{psi}(1.85 \mathrm{~mL} / \mathrm{min})$. A Flame Ionization detector (FID) was used at $265^{\circ} \mathrm{C}$. The temperature program was $60^{\circ} \mathrm{C}$ for 2 min, then increased to $180^{\circ} \mathrm{C}$ at $10^{\circ} \mathrm{C} / \mathrm{min}$, and then increased to $235^{\circ} \mathrm{C}$ at $4^{\circ} \mathrm{C} / \mathrm{min}$. Results were reported as percent of the total fatty acids based on peak areas according to AOCS CE $1 \mathrm{f}-96$ (Firestone, 2004).

\subsection{Determination of Phytosterols}

Phytosterols were analysed as trimethylsilylesters based on the method outlined in Maguire, O'Sullivan, Galvin, O'Connor, \& O'Brien (2004) using the expressed cashew oil $(\mathrm{n}=3)$. An internal standard of $5 \alpha$ cholestane in ethanol was added to the oil samples which were then saponified with ethanolic potassium hydroxide and the unsaponifiable matter including the phytosterols were extracted into hexane. The solvent was evaporated to a single $\mathrm{mL}$ and then derivatized using BSTFA-Regisil ${ }^{\circledR}$ with pyridine as a catalyst. A Perkin Elmer (Shelton, CT) Autosampler XL gas chromatograph fitted with an FID detector set at $305^{\circ} \mathrm{C}$. The column was a DB-5 (J\&W, Folsom, CA) (30 m length, $0.25 \mathrm{~mm}$ i.d., $0.25 \mu \mathrm{m}$ film thickness). The injector was a split, packed type set at $235^{\circ} \mathrm{C}$ with a split flow ratio of $70 \mathrm{~mL} / \mathrm{min}$ and helium at $1.3 \mathrm{~mL} / \mathrm{min}$ was the carrier gas. The temperature program was: $100^{\circ} \mathrm{C}$ for $0.2 \mathrm{~min}$, with an increase to $305^{\circ} \mathrm{C}$ at $10^{\circ} \mathrm{C} / \mathrm{min}$, and held for $15 \mathrm{~min}$. Phytosterols were calculated using relative response factors for each sterol calculated from a standard mixture of phytosterols derivatized in the same way as the samples.

\subsection{Determination of Phospholipids}

The phospholipids (PL) present in cashews were identified using methods adapted from Donato et al. (2011) and Lee, Welti, Schapaugh, \& Trick (2011). PL were extracted from the expressed oils $(\mathrm{n}=3)$ using 2:1 (vol/vol) chloroform/methanol 3 times and dried to a volume of $1 \mathrm{~mL}$ of solvent for 3 hours using a TurboVap (Biotage, Uppsala, Sweden). The extracts were brought up in $1.5 \mathrm{~mL}$ of methanol $(2: 1 \mathrm{v} / \mathrm{v})$. Solid phase extraction was used to extract polar lipids from the neutral lipids using Supelco silica normal phase $5 \mathrm{mg}$ SPE cartridges (Sigma-Aldrich, St. Louis, MO). The cartridges were conditioned with $4 \mathrm{~mL}$ hexane and $0.5 \mathrm{~mL}$ of sample were 
loaded. Neutral lipids were eluted using $3 \mathrm{~mL}$ of hexane/ethyl ether $(8: 1 \mathrm{v} / \mathrm{v})$ followed by $3 \mathrm{~mL} 1: 1$ hexane/ethyl ether $(1: 1 \mathrm{v} / \mathrm{v})$. Polar lipids were eluted with $4 \mathrm{~mL}$ of methanol, followed by $2 \mathrm{~mL}$ of methanol, and $2 \mathrm{~mL}$ of chloroform $/ \mathrm{methanol} /$ water $(3: 5: 2 \mathrm{v} / \mathrm{v} / \mathrm{v})$. The polar lipids were collected and the solvents were evaporated under nitrogen. The polar lipids were then solubilized in $0.5 \mathrm{~mL}$ chloroform/methanol $(2: 1 \mathrm{v} / \mathrm{v})$ and filtered through a $0.2 \mu \mathrm{m}$ PTFE filter (Millex-GV, PVDF, Millipore Corp., Billerica, MA) into amber HPLC vials. The samples were analysed by HPLC using a Waters Ultra Performance system (Waters Corp., Milford, MA) equipped with an evaporative light scattering detector. The column was a Waters BEH HILIC $(1.7 \mu \mathrm{m} 150 \times 2.1 \mathrm{~mm})$. The column oven set at $30^{\circ} \mathrm{C}$. The drift tube temperature was $85^{\circ} \mathrm{C}$ and the nitrogen flow rate was $1.75 \mathrm{~L} / \mathrm{min}$. Gradient elution was used with $100 \%$ acetonitrile (mobile phase A), 100\% water (mobile phase B), and $200 \mathrm{mM}$ ammonium acetate, $\mathrm{pH} 5.5$ (mobile phase $\mathrm{C}$ ) at a flow rate of $0.6 \mathrm{~mL} / \mathrm{min}$. The gradient was $95 \% \mathrm{~A}$ and $5 \% \mathrm{C}$ for $2 \mathrm{~min}$, then B was increased to $22 \%$ while $\mathrm{C}$ was held at $5 \%$. After $1 \mathrm{~min}$, B was decreased to $0 \%$ again and the system was re-equilibrated. PL in the samples were quantified using external standard curves of phosphatidylcholine, phosphatidylserine, phosphatidylethanolamine, and sphingomyelin.

\subsection{Determination of Sugars}

Defatted cashew flour was used for the analysis of sugars in the cashews as previously described (Pattee, Isleib, Giesbrecht, \& McFeeters, 2000). Sugars were extracted $(\mathrm{n}=3)$ with $15 \mathrm{~mL}$ of chloroform/methanol/water $(65: 25: 15, \mathrm{v} / \mathrm{v} / \mathrm{v})$. The solvent was evaporated and $1 \mathrm{~mL}$ of internal standard solution containing lactose and cellobiose in water was used to rehydrate the residue. Finally, $50 \mu \mathrm{L}$ of each sample solution was diluted to $2 \mathrm{~mL}$ with water, passed through a Dionex OnGuard-H filter (Dionex, Sunnyvale, CA), and injected onto a Dionex Bio LC system. A Dionex CarboPac ${ }^{\mathrm{TM}}$ PA-1 column $(250 \mathrm{~mm}$ length, $4 \mathrm{~mm}$ i.d.) and a Pulsed Amperometric Detector (PAD) was used. The column was heated to $25^{\circ} \mathrm{C}$. The mobile phase was $200 \mathrm{mM}$ sodium hydroxide at a flow rate of $1.0 \mathrm{~mL} / \mathrm{min}$. Sugars were quantified using response factors calculated from a mix of all the standards injected with the samples.

\subsection{Determination of Vitamins}

Microbiological test kits from VitaFast ${ }^{\circledR}$ were purchased from r-biopharm (Darmstadt, Germany) for the analysis of thiamin and riboflavin. Sample preparation and analyses were performed $(n=3)$ according to the test kit specifications.

Niacin was measured according to the AOAC method 961.14 (Latimer, 2012). Samples $(n=3)$ were digested with $1 \mathrm{~N}$ sulfuric acid in an autoclave (Amsco Scientific Series 3021-S Gravity, Steris, Mentor, OH). The pH was adjusted to 4.5 with $10 \mathrm{~N}$ sodium hydroxide, and samples were filtered. The niacin extracted into the supernatant was complexed with cyanogen bromide to form a purple color. The absorbance of the solutions was read on a Genesys 20 UV-VIS spectrophotometer (Thermo Fisher Scientific, Fairlawn, NJ) at $470 \mathrm{~nm}$ and compared to an external standard curve prepared from an authentic nicotinic acid solution.

Tocopherols were measured in the cashew oil $(\mathrm{n}=3)$ by normal phase HPLC. $200 \mathrm{mg}$ of expressed cashew oil was combined with $0.8 \mathrm{~mL}$ of 1\% 2-propanol in hexane as previously described (Hashim, Koehler, Eintenmiller, \& Kvien, 1993). The HPLC was an Agilent Model 1100 series (Agilent Technologies, Santa Clara, CA) fitted with a Luna Silica column ( $250 \mathrm{~mm}$ X $4.6 \mathrm{~mm}$ i.d., $5 \mu$, Phenomenex, Torrance, CA). The mobile phase was $1 \%$ 2-propanol in hexane at a flow rate of $1.2 \mathrm{~mL} / \mathrm{min}$. The detection was by UV at $294 \mathrm{~nm}$. An external standard curve consisting of a mix of $\alpha, \beta, \gamma$, and $\Delta$ tocopherols was used for quantification of tocopherols.

Vitamin $\mathrm{K}$ was analysed in the expressed oils from the samples $(\mathrm{n}=3)$ using the normal phase HPLC system described in the previous section. The flow rate of the mobile phase was $1.0 \mathrm{~mL} / \mathrm{min}$ and the detector wavelength was $248 \mathrm{~nm}$ as described by Otles and Cagindi (2007). External curves of vitamin $\mathrm{K}_{1}$ and Vitamin $\mathrm{K}_{2}$ were prepared in hexane and used for quantification (Piironen \& Koivu, 2000).

For analysis of the carotenoids, samples $(\mathrm{n}=3)$ were saponified using $2 \mathrm{~mL}$ of $2.5 \%$ pyrogallol in ethanol and 1 $\mathrm{mL}$ of $50 \%$ potassium hydroxide in a $38^{\circ} \mathrm{C}$ water bath for 4 hours (Trox et al., 2010). The carotenoids were extracted with hexane, dried under nitrogen, and redissolved in $200 \mu \mathrm{L}$ of ethanol. Samples were analysed by HPLC (Agilent Model 1100, Agilent Technologies, Santa Clara, CA) using a Luna Silica $5 \mu$ column (250 mm length, $4 \mathrm{~mm}$ i.d., Phenomenex, Torrance, CA). The mobile phase was $82 \%$ acetonitrile, $15 \%$ dioxane, and $3 \%$ methanol containing $100 \mathrm{mM}$ ammonium acetate and $0.1 \%$ trimethylamine. The UV/Vis detector was set to 450 $\mathrm{nm}$. An external standard curve was generated from an authentic $\beta$-carotene solution for the quantification of carotenoids.

\subsection{Determination of Minerals}

The minerals in the cashews were analyzed by the Analytical Spectroscopy Service Laboratory at the North 
Carolina State University (Raleigh, NC). Inductively Coupled Plasma (ICP) spectroscopy was used to measure sodium, potassium, magnesium, phosphorous, iron, zinc, manganese, and copper $(\mathrm{n}=3)$.

\subsection{Determination of Phenolic Content and Bioactivity}

The Folin-Ciocalteau assay was used to determine the total phenolic content in the samples (Singleton, Orthofer, \& Lamuela-Raventos, 1999). The phenolics were extracted from the ground samples $(n=3)$ using a ten-fold volume of $80 \%$ acidified ethanol. After sonication to extract the phenolics, and centrifugation, $0.1 \mathrm{~mL}$ of the clear supernatant was diluted with $7.9 \mathrm{~mL}$ water, and $0.5 \mathrm{~mL}$ of Folin-Ciocalteau reagent and $1.5 \mathrm{~mL}$ of sodium carbonate solution $(20 \% \mathrm{w} / \mathrm{v}$ in water) were added. The samples were incubated in the dark for 2 hours at ambient temperature. The absorbance was read at $765 \mathrm{~nm}$ using a Genesys 20 UV-VIS spectrophotometer (Thermo Fisher Scientific, Fairlawn, NJ). Gallic acid standards were prepared ranging from 0 to $750 \mathrm{mg}$ gallic $\mathrm{acid} / \mathrm{L}$ and treated as samples. Total phenolics were determined by conversion from the gallic acid standard curve and expressed as milligram gallic acid equivalents (GAE) per 100 grams of sample.

Procyanidins were analysed as described previously (Constanza, White, Davis, Sanders, \& Dean, 2012). They were extracted with $1 \mathrm{~mL}$ of $70 \%$ ethanol per $0.2 \mathrm{~g}$ of defatted cashew samples $(\mathrm{n}=3)$. The samples were sonicated, centrifuged, and filtered through $0.22 \mu$ filters (Millex-HV, PVDF, Millipore Corp., Billerica, MA). The extracts were ionized analysed using a Dionex Summit HPLC (Dionex Corp., Sunnyvale, CA). The HPLC was fitted with a Luna silica column (5 $\mu \mathrm{m}, 250 \mathrm{x}$ 4.6, Phenomenex, Torrance, CA), and an RF2000 fluorescence detector. Fluorescence was monitored with an excitation wavelength of $276 \mathrm{~nm}$ and an emission wavelength of $316 \mathrm{~nm}$. Monomers, dimers, trimers, and tetramers were quantified based on an external standard curves of catechin, epicatichin, procyanidin A2, a procyanidin trimer, and a procyanidin tetramer.

The total antioxidant activity of the samples was measured using the 2,2-diphenyl-1-picrylhydrazyl (DPPH) assay according to the AOAC Method 1012.04 (Latimer, 2012). The antioxidants were extracted from whole cashew homogenates $(n=3)$ using $80 \%$ methanol with a Mars 6 Microwave Digester (CEM, Matthews, NC). Upon cooling, samples were filtered and diluted to $50 \mathrm{~mL}$ in $80 \%$ methanol. Aliquots of $0.1 \mathrm{~mL}$ (raw and dry-roasted) and $10 \mu \mathrm{L}$ (wrapped) were combined with $5 \mathrm{~mL}$ of $40 \mathrm{mg} / \mathrm{L}$ DPPH reagent in methanol. A Trolox standard was prepared in methanol and diluted with methanol to create a standard curve with a range of 0.01 to $0.05 \mathrm{mg} / \mathrm{mL}$. $5 \mathrm{~mL}$ of DPPH solution was added as per the samples. Samples and standards were incubated at $35^{\circ} \mathrm{C}$ for 2 hours in the dark and absorbance was analysed using a Genesys 20 UV-VIS spectrophotometer (Thermo Fisher, Fairlawn, NJ) set at $517 \mathrm{~nm}$. DPPH (\%) quenched was calculated from the data and plotted against the weight of Trolox standard to generate a standard curve. Total antioxidant activity was determined by conversion from the Trolox standard curve and expressed as milligram Trolox equivalents (TE) per gram of sample (Plank et al., 2012).

Oxygen radical absorbance capacity (ORAC) was measured in the samples as described by Constanza et al. (2012). The active compounds were extracted from defatted cashew samples $(\mathrm{n}=3)$ with $15 \mathrm{~mL}$ of $0.5 \%$ acetic acid in methanol. After extraction, samples were diluted 10 fold in $0.075 \mathrm{M}$ potassium phosphate buffer. A Trolox standard curve ranging from 3.175 to $50 \mu \mathrm{M}$ was prepared in phosphate buffer. Samples and standards were pipetted into a Costar polystyrene flat bottom black 96-well plate (Coring, Inc., Acton, MA) in $130 \mu \mathrm{L}$ aliquots, followed rapidly by $60 \mu \mathrm{L}$ of $3480 \mathrm{nM}$ fluorescein in phosphate buffer. The plate was incubated at $37^{\circ} \mathrm{C}$ for 15 minutes before the peroxyl radical generator, 2,2'-azobis(2-amidinopropane) dihydrochloride (AAPH) (152 mM in phosphate buffer) was added to each well in a $60 \mu \mathrm{L}$ aliquot. The plate was incubated at $37^{\circ} \mathrm{C}$ for 90 minutes in a Safire ${ }^{2}$ plate reader (Tecan, Inc., Durham, NC). Just before reading, the plate was shaken at medium orbital intensity for $5 \mathrm{~s}$. The data was collected over 90,1 min kinetic cycles with a $5 \mathrm{~s}$ shaking interlude between each cycle. The resulting data were reported in relative fluorescence units (RFU) and exported into Microsoft Xcel (Microsoft, Roselle, IL) for determination of the antioxidant capacity as $\mu \mathrm{g}$ Trolox equivalents (TE) per $100 \mathrm{~g}$ of whole nut.

\subsection{Determination of Cashew Nut Shell Liquid}

Residual CNSL was detected in the cashew samples based on a method outlined in Paramashivappa, Kumar, Vithayathil, \& Rao (2001). Cashew homogenate $(\mathrm{n}=3)$ was placed in a Soxlet apparatus and cashew oil was extracted using hexane for 6 hours. The hexane was evaporated and $0.05 \mathrm{~g}$ of the residue was dissolved in $5 \mathrm{~mL}$ of acetonitrile. The samples were analysed using a Dionex Summit HPLC system (Dionex, Sunnyvale, CA) fitted with a LiChrospher 100 RP-18 column ( 250 x $4.6 \mathrm{~mm}$ column, $5 \mu$, Alltech Assoc., Deerfield, IL). The mobile phase acetonitrile:water:acetic acid (80:20:1 v/v/v) at $1.0 \mathrm{~mL} / \mathrm{min}$ and $\mathrm{UV}$ detection at $280 \mathrm{~nm}$ was used. CNSL was quantified based on an external standard curve prepared in acetonitrile using authentic CNSL (Gift of Dr. Mihail Ionescu, Pittsburg State University, KS). 


\subsection{Statistical Analysis}

Results for each analysis are expressed as means \pm standard deviation. Analysis of variance coupled with Tukey's highly significant difference test was performed using JMP Pro 12 (SAS, Cary, NC) to determine if there were differences between samples. In the cases where the variances were unequal and analysis of variance was inappropriate, Wilcoxon's test with multiple comparisons was used.

\section{Results and Discussion}

\subsection{Proximates}

The moisture content of the cashews ranged from 2.5 to $4.57 \%$. All sample moistures were significantly different from each other (Table 1). The dry-roasted and wrapped nuts had significantly less moisture than the raw nuts due to the roasting process. The moisture content of cashews has been found to vary due to location and environmental factors (Rico et al. 2015).

Table 1. Proximate Analysis of Cashew Nuts

\begin{tabular}{llll}
\hline & Raw & Dry-Roasted & Wrapped \\
\hline Moisture \% WWB & $4.57^{\mathrm{a}} \pm 0.22$ & $3.12^{\mathrm{b}} \pm 0.88$ & $2.50^{\mathrm{c}} \pm 0.11$ \\
Total Oil \% & $6.4^{\mathrm{a}} \pm 1.2$ & $46.4^{\mathrm{a}} \pm 1.0$ & $44.9^{\mathrm{a}} \pm 0.86$ \\
Total Carbohydrate* \% & 29.8 & 31.0 & 28.3 \\
Total Protein \% & $17.2^{\mathrm{a}} \pm 0.13$ & $17.5^{\mathrm{a}} \pm 0.40$ & $15.3^{\mathrm{b}} \pm 0.30$ \\
\hline
\end{tabular}

*by subtraction, assuming $2 \%$ ash and $7 \%$ skins

Different letters signify statistical significance across rows, $\mathrm{p}<0.05$

Total oil content was similar in samples and ranged from 44.9 to $46.4 \%$ (Table 1). Lipid was the primary nutritional constituent of cashew nuts, as lipids act as an energy reserve for the seeds of plants (Lim, 2012). Although it has been noted that lipids are the primary constituent of all edible nuts, cashews have lower levels of total lipids. Reportedly, hazelnuts, pecans, Brazil nuts, pine nuts, and macadamia nuts all contain at least $60 \%$ oil. Only peanuts $(42 \%)$ have less oil than the cashews analyzed in this study (Venkatachalam \& Sathe, 2006).

Total carbohydrate was calculated by difference from the proximate content, assuming $2 \%$ ash and $7 \%$ skins in the wrapped product (Table 1). Carbohydrate content ranged from 28.3 to $31.0 \%$, which was consistent with other reports for cashew nuts. Cashews have been reported to contain more carbohydrates than other nut types. The average carbohydrate content of roasted tree nuts is $19.6 \%$ with a range of $7.8 \%$ in macadamia nuts to $29.9 \%$ in cashews (Brufau, Boatella, \& Rafecas, 2006).

Total protein ranged from 15.3 to $17.5 \%$ (Table 1 ). The wrapped nuts had significantly less protein than the other two nut types, which was attributed to protein leaching during the water washing step to remove CNSL from the skins (Nair, 2003). Cashews, along with almonds (22\%) and pistachios (21\%), have the highest reported levels of protein in tree nuts. However; this does not take into account that the biological value of all nuts is low due to limiting essential amino acids, especially lysine (Brufau et al., 2009).

\subsection{Amino Acid Profiles}

The amino acid profiles of the cashews are reported in Table 2. No significant differences were detected across the samples in the 17 amino acids quantified, indicating no deleterious effects on the amino acid profile of the cashew varieties due to heat processing or water washing. Glutamic acid and tryptophan were the most and least abundant amino acids present in the samples, respectively. Furthermore, it was clear that amino acids with acidic side groups were overall the most abundant, followed by amino acids with aliphatic side groups. This observation is consistent with other nut types (Venkatachalam \& Sathe, 2006). 
Table 2. Amino Acid Profile of Cashew Nuts

\begin{tabular}{llll}
\hline Amino Acid (g/100g) & Raw & Dry-Roasted & Wrapped \\
\hline Aspartic Acid & $1.37^{\mathrm{a}} \pm 0.01$ & $1.23^{\mathrm{a}} \pm 0.22$ & $1.38^{\mathrm{a}} \pm 0.06$ \\
Threonine & $0.53^{\mathrm{a}} \pm 0.1$ & $0.47^{\mathrm{a}} \pm 0.08$ & $0.53^{\mathrm{a}} \pm 0.02$ \\
Serine & $0.78^{\mathrm{a}} \pm 0.3$ & $0.71^{\mathrm{a}} \pm 0.12$ & $0.79^{\mathrm{a}} \pm 0.03$ \\
Glutamic Acid & $3.34^{\mathrm{a}} \pm 0.1$ & $3.0^{\mathrm{a}} \pm 0.53$ & $3.19^{\mathrm{a}} \pm 0.13$ \\
Glycine & $0.68^{\mathrm{a}} \pm 0.02$ & $0.61^{\mathrm{a}} \pm 0.11$ & $0.69^{\mathrm{a}} \pm 0.03$ \\
Alanine & $0.57^{\mathrm{a}} \pm 0.02$ & $0.51^{\mathrm{a}} \pm 0.09$ & $0.58^{\mathrm{a}} \pm 0.02$ \\
Valine & $0.80^{\mathrm{a}} \pm 0.02$ & $0.72^{\mathrm{a}} \pm 0.13$ & $0.77^{\mathrm{a}} \pm 0.03$ \\
Methionine & $0.37^{\mathrm{a}} \pm 0.01$ & $0.32^{\mathrm{b}} \pm 0.07$ & $0.33^{\mathrm{b}} \pm 0.01$ \\
Cysteine & $0.56^{\mathrm{a}} \pm 0.01$ & $0.50^{\mathrm{a}} \pm 0.08$ & $0.55^{\mathrm{a}} \pm 0.02$ \\
Isoleucine & $0.61^{\mathrm{a}} \pm 0.01$ & $0.55^{\mathrm{a}} \pm 0.09$ & $0.60^{\mathrm{a}} \pm 0.02$ \\
Leucine & $1.02^{\mathrm{a}} \pm 0.02$ & $0.92^{\mathrm{a}} \pm 0.15$ & $1.01^{\mathrm{a}} \pm 0.04$ \\
Tryptophan & $0.14^{\mathrm{a}} \pm 0.01$ & $0.12^{\mathrm{a}} \pm 0.02$ & $0.13^{\mathrm{a}} \pm 0.01$ \\
Phenylalanine & $0.68^{\mathrm{a}} \pm 0.02$ & $0.62^{\mathrm{a}} \pm 0.1$ & $0.68^{\mathrm{a}} \pm 0.03$ \\
Lysine & $0.60^{\mathrm{a}} \pm 0.01$ & $0.55^{\mathrm{a}} \pm 0.09$ & $0.56^{\mathrm{a}} \pm 0.02$ \\
Histidine & $0.43^{\mathrm{a}} \pm 0.14$ & $0.31^{\mathrm{a}} \pm 0.05$ & $0.33^{\mathrm{a}} \pm 0.01$ \\
Arginine & $1.2^{\mathrm{a}} \pm 0.78$ & $1.5^{\mathrm{a}} \pm 0.26$ & $1.6^{\mathrm{a}} \pm 0.06$ \\
Proline & $0.75^{\mathrm{a}} \pm 0.3$ & $0.51^{\mathrm{a}} \pm 0.09$ & $0.57^{\mathrm{a}} \pm 0.02$ \\
Total & $14.9 \pm 0.01$ & $13.5 \pm 2.3$ & $14.6 \pm 0.55$ \\
\hline
\end{tabular}

Different letters across rows signify significantly different values, $\mathrm{p}<0.05$.

Since variances were unequal, Wilcoxon's test with multiple comparisons was used.

It was noted that arginine was the second most abundant amino acid found in the samples which is related to the role of arginine as a storage and carrier form of nitrogen in plants. This was consistent with other nut types (Shi \& Chan, 2013; Venkatachalam \& Sathe, 2006). Studies have also indicated that arginine plays a role in the vasodilation of blood vessels in the human body. Arginine is thought to be a contributing factor to reducing the risk for cardiovascular disease. The arginine in the cashews, although not as concentrated as the amount in other nuts, adds to consideration of cashews to be labeled as a heart-healthy food, along with the monounsaturated fatty acids (MUFA), polyunsaturated fatty acids (PUFA), and phytosterols present in the nuts (King, Blumberg, Ingwersen, Jenab, \& Tucker, 2008; Kris-Etherton, Hu, Rose, \& Sabate, 2008; Venkatachalam \& Sathe, 2006).

\subsection{Lipid Analysis}

The fatty acid profile of the cashews determined by GC is presented in Table 3. Very few significant differences were found between the samples and the greatest differences were observed in unsaturated fatty acids. It is possible that the minor differences were due to fatty acid oxidation due to processing heat. Oxidation can occur in oils at temperatures as low as $40^{\circ} \mathrm{C}$, but is not necessarily uniform across samples or batches (Moreno, Olivares, Lopez, Adelantado, \& Reig, 1999). Differences were likely not observed in the saturated fatty acids because their lack of double bonds protects them from oxidation and thus they would not change due to processing. Changes in fatty acids have been observed in heat treatments including blanching, roasting, and drying, all of which the cashews analyzed in this study have been subjected to (Luh, Wong, \& El-Shimi, 1981). 
Table 3. Fatty Acid Profile of Cashew Nuts

\begin{tabular}{|c|c|c|c|}
\hline Fatty Acid (\%) & Raw & Dry-Roasted & Wrapped \\
\hline C 14:0 & $0.01^{\mathrm{a}} \pm 0.01$ & $0.02^{\mathrm{a}} \pm 0.00$ & $0.02^{\mathrm{a}} \pm 0.00$ \\
\hline C $16: 0^{*}$ & $10.3^{\mathrm{a}} \pm 0.04$ & $10.4^{\mathrm{a}} \pm 0.01$ & $10.4^{\mathrm{a}} \pm 0.06$ \\
\hline C $16: 1$, cis $^{*}$ & $0.37^{\mathrm{a}} \pm 0.00$ & $0.38^{\mathrm{b}} \pm 0.00$ & $0.37^{\mathrm{ab}} \pm 0.00$ \\
\hline C $17: 0$ & $0.12^{\mathrm{a}} \pm 0.00$ & $0.12^{\mathrm{a}} \pm 0.00$ & $0.12^{\mathrm{a}} \pm 0.00$ \\
\hline C $17: 1$, cis & $0.05^{\mathrm{a}} \pm 0.00$ & $0.05^{\mathrm{a}} \pm 0.00$ & $0.05^{\mathrm{a}} \pm 0.00$ \\
\hline C $18: 0^{*}$ & $8.8^{\mathrm{a}} \pm 0.01$ & $9.2^{\mathrm{a}} \pm 0.01$ & $9.2^{\mathrm{a}} \pm 0.04$ \\
\hline C $18: 1^{*}$ & $61.8^{\bar{a}} \pm 0.03$ & $61.7^{\bar{a}} \pm 0.02$ & $61.3^{\bar{a}} \pm 0.08$ \\
\hline C $18: 2$ & $17.3^{\mathrm{a}} \pm 0.01$ & $16.7^{\mathrm{b}} \pm 0.02$ & $17.2^{\mathrm{c}} \pm 0.04$ \\
\hline C $18: 3^{*}$ & $0.14^{\mathrm{a}} \pm 0.00$ & $0.13^{\mathrm{a}} \pm 0.01$ & $0.14^{\mathrm{a}} \pm 0.00$ \\
\hline C $20: 0^{*}$ & $0.62^{\mathrm{a}} \pm 0.01$ & $0.64^{\mathrm{a}} \pm 0.00$ & $0.63^{\mathrm{a}} \pm 0.01$ \\
\hline C $20: 1^{*}$ & $0.19^{\mathrm{a}} \pm 0.00$ & $0.18^{\mathrm{b}} \pm 0.00$ & $0.18^{\mathrm{ab}} \pm 0.01$ \\
\hline C 22:0 & $0.13^{\mathrm{a}} \pm 0.00$ & $0.13^{\mathrm{a}} \pm 0.00$ & $0.13^{\mathrm{a}} \pm 0.00$ \\
\hline C 22:1, cis & $0.01^{\mathrm{a}} \pm 0.01$ & $0.01 \pm 0.01^{\mathrm{a}}$ & $0.01^{\mathrm{a}} \pm 0.01$ \\
\hline C 24:0 & $0.14^{\mathrm{a}} \pm 0.00$ & $0.14^{\mathrm{a}} \pm 0.00$ & $0.14^{\mathrm{a}} \pm 0.01$ \\
\hline C 26:0 & $0.01^{\mathrm{a}} \pm 0.01$ & $0.02^{\mathrm{a}} \pm 0.00$ & $0.01^{\mathrm{a}} \pm 0.01$ \\
\hline Others & $0.26^{a} \pm 0.00$ & $0.27^{\mathrm{a}} \pm 0.01$ & $0.26^{a} \pm 0.03$ \\
\hline $\mathrm{P} / \mathrm{S}$ & $0.86^{\mathrm{a}} \pm 0.00$ & $0.93^{\mathrm{b}} \pm 0.00$ & $0.90^{\mathrm{c}} \pm 0.01$ \\
\hline$\%$ Saturation & $20.1^{\mathrm{a}} \pm 0.05$ & $20.7^{\mathrm{a}} \pm 0.01$ & $20.7^{a} \pm 0.04$ \\
\hline
\end{tabular}

Others refers to the fatty acids not otherwise accounted for. Others $=100-\sum$ fatty acids in Table 3

$\mathrm{P} / \mathrm{S}$ is the ratio of polyunsaturated fatty acids to saturated fatty acids

$\%$ Saturation refers to the amount of fatty acids in the sample that have no double bonds

Different letters across rows signify significantly different values, $\mathrm{p}<0.05$.

Pairwise differences determined by Tukey's HSD

* Since variances were unequal, Wilcoxon's test with multiple comparisons was used.

The predominant MUFA was oleic acid (C18:1) and the predominant PUFA was linoleic acid (C18:2). Saturated fatty acids that were most prominent in the nuts were palmitic acid (C16:0) and stearic acid (C18:0). These observations were consistent with the fatty acid profiles of other nuts and other studies involving cashews (Venkatachalam \& Sathe, 2006). However, studies involving other nuts have indicated that the levels of unsaturated fatty acids are much higher in other nuts compared to cashews. Table 3 shows that the cashews had only $61 \%$ oleic acid and $17 \%$ linoleic acid. In contrast, almonds contain $69 \%$ oleic acid, hazelnuts contain $79 \%$ oleic acid, peanuts contain 44\% linoleic acid, and walnuts contain 57\% linoleic acid. (Maguire et al., 2004; Ryan, Glavin, O'Connor, Maguire, \& O'Brien, 2006). Despite the lower levels of unsaturated fatty acids in the cashews compared to other tree nuts, consumption of cashews could still be associated with reduced risk of cardiovascular disease. The majority of the fatty acids in the cashews are those that have the ability to reduce LDL cholesterol (Kris-Etherton et al., 2008).

Plant sterols are essential to the functionality of cell membranes of all eukaryotic cells. They also play a key role in cellular differentiation and proliferation of plant cells. For this reason, phytosterols are stored in the lipid portions of plant seeds for future growth (Piironen, Lindsay, Miettinen, Toivo, \& Lampi, 2000). Cashew nuts were analyzed for their phytosterol content (Table 4). Consistent with other nuts, $\beta$-sitosterol was the predominant sterol present across samples. However, the total amount of phytosterols found in this study (200 $\mathrm{mg} / 100 \mathrm{~g}$ ) was higher than those found in other studies involving oil-roasted cashews (158 $\mathrm{mg} / 100 \mathrm{~g})$ and other nuts including Brazil nuts $(95 \mathrm{mg} / 100 \mathrm{~g})$, peanuts $(135 \mathrm{mg} / 100 \mathrm{~g})$, hazelnuts $(121 \mathrm{~g} / 100 \mathrm{~g})$, and walnuts (113 $\mathrm{mg} / 100 \mathrm{~g}$ ) (Phillips et al., 2005). Given that the nuts analyzed here had more phytosterols than oil-roasted cashews, it would seem likely that the dry-roasting heat treatment was less harsh on phytosterol content than traditional oil-roasting. Although phytosterols have been recognized for their ability to reduce cholesterol levels in the human body, the levels found in the cashews do not qualify for an FDA approved health claim (Winkler, Warner, \& Glynn, 2007). 
Table 4. Phytosterol Content of Cashew Nuts

\begin{tabular}{llll}
\hline Phytosterol (mg/100g) & Raw & Dry-Roasted & Wrapped \\
\hline Brassicasterol & $0.75^{\mathrm{a}} \pm 0.5$ & $0.11^{\mathrm{a}} \pm 0.2$ & $0.26^{\mathrm{a}} \pm 0.3$ \\
Campesterol & $14.2^{\mathrm{a}} \pm 1.3$ & $14.6^{\mathrm{a}} \pm 2.7$ & $15.1^{\mathrm{a}} \pm 2.9$ \\
Stigmasterol & $1.0^{\mathrm{a}} \pm 0.6$ & $1.24^{\mathrm{a}} \pm 0.5$ & $5.1^{\mathrm{b}} \pm 0.3$ \\
B-Sitosterol & $152.1^{\mathrm{a}} \pm 28.7$ & $173.7^{\mathrm{a}} \pm 30.2$ & $172.4^{\mathrm{a}} \pm 41.3$ \\
\hline
\end{tabular}

Different letters across rows signify significantly different values, $\mathrm{p}<0.05$.

Pairwise differences determined by Tukey's HSD

Phospholipids (PL) play a structural role in all cell membranes, but also act as secondary messengers in regulation in plant growth and stress adaptation (Xue, Chen, \& Mei, 2009). As such, phospholipids were measured in the cashew samples (Table 5). It was observed that phosphatidylcholine was the most prominent PL in the samples, consistent with other nut types. Some significant differences were detected in the levels of PL in the samples. It has been reported in other studies involving nuts that heat treatment can decrease total PL levels. Additionally, moisture levels and temperature can affect PL levels and the relative ratios of specific isoforms. These observations could explain the variations in PL levels across the samples (Davis \& Dean, 2016).

Table 5. Phospholipid Content of Cashew Nuts

\begin{tabular}{llll}
\hline Phospholipid (mg/100g) & Raw & Dry-Roasted & Wrapped \\
\hline Phosphatidylcholine & $241.7^{\mathrm{ab}} \pm 14.9$ & $276.7^{\mathrm{a}} \pm 30.8$ & $229.6^{\mathrm{b}} \pm 22.8$ \\
Phosphatidylserine $^{*}$ & $45.6^{\mathrm{ab}} \pm 6.1$ & $51.4^{\mathrm{a}} \pm 10.2$ & $33.4^{\mathrm{b}} \pm 9.8$ \\
Phosphatidylethanolamine $^{*}$ & $41.9^{\mathrm{a}} \pm 14.8$ & $25.0^{\mathrm{a} \mathrm{b}} \pm 2.91$ & $14.7^{\mathrm{b}} \pm 5.92$ \\
Sphingomyelin $_{\text {Total }}$ & $13.8^{\mathrm{a}} \pm 5.0$ & $10.5^{\mathrm{a}} \pm 6.5$ & $11.6^{\mathrm{a}} \pm 6.0$ \\
& $343.3^{\mathrm{a}} \pm 35.6$ & $403.2^{\mathrm{a}} \pm 90.8$ & $289.4^{\mathrm{b}} \pm 39.7$ \\
\hline
\end{tabular}

Different letters across rows signify significantly different values, $\mathrm{p}<0.05$.

Pairwise differences determined by Tukey's HSD

\subsection{Sugar Composition}

The cashews were analysed for mono, di, and oligosaccharides (Table 6). The total sugars in cashews according to this study were higher than other nut types. Total carbohydrates, including sugars are higher in cashews as the balance with the lower lipid levels compared to other nuts is needed (Venkatachalam \& Sathe, 2006). This is related to the growth habit of cashew as more closely tied to a fruit, rather than an isolated seed. No significant differences were observed between the varieties in the disaccharides and oligosaccharides analysed. In contrast, significant differences were observed across all samples in the monomer units, with the highest concentrations of monomers found in the wrapped nuts.

Table 6. Sugar Content of Cashew Nuts

\begin{tabular}{llll}
\hline Sugar $(\mathrm{g} / \mathbf{1 0 0 g})$ & Raw & Dry-Roasted & Wrapped \\
\hline Inositol & $0.049^{\mathrm{a}} \pm 0.002$ & $0.053^{\mathrm{b}} \pm 0.001$ & $0.061^{\mathrm{c}} \pm 0.001$ \\
Glucose & $0.012^{\mathrm{a}} \pm 0.001$ & $0.019^{\mathrm{b}} \pm 0.002$ & $0.039^{\mathrm{c}} \pm 0.003$ \\
Fructose & $0.010^{\mathrm{a}} \pm 0.001$ & $0.024^{\mathrm{b}} \pm 0.003$ & $0.065^{\mathrm{c}} \pm 0.004$ \\
Sucrose & $3.6^{\mathrm{a}} \pm 0.16$ & $3.8^{\mathrm{a}} \pm 0.009$ & $3.5^{\mathrm{a}} \pm 0.079$ \\
Raffinose & $1.8^{\mathrm{a}} \pm 0.069$ & $1.8^{\mathrm{a}} \pm 0.085$ & $1.7^{\mathrm{a}} \pm 0.028$ \\
Stachyose & $0.54^{\mathrm{a}} \pm 0.033$ & $0.58^{\mathrm{a}} \pm 0.035$ & $0.57^{\mathrm{a}} \pm 0.008$ \\
Total & $6.0^{\mathrm{a}} \pm 0.26$ & $6.3^{\mathrm{a}} \pm 0.12$ & $5.9^{\mathrm{a}} \pm 0.11$ \\
\hline
\end{tabular}

Different letters across rows signify significantly different values, $\mathrm{p}<0.05$.

Pairwise differences determined by Tukey's HSD

* Since variances were unequal, Wilcoxon's test with multiple comparisons was used

Disaccharides such as sucrose are known to hydrolyze due to heat processing, especially if nuts are not properly dried after harvesting. Sucrose will break down into its component monomer units, glucose and fructose, which can then participate in Maillard browning (Luh et al, 1981; Wall \& Gentry, 2007). Additionally, studies have 
indicated that many phenolic compounds exist in foods attached to a sugar moiety, commonly glucose (Rein et al., 2013). Thermal processing can degrade phenolic compounds, thus breaking off the sugar monomers in the process (Buchner, Krumbein, Rohn, \& Kroh, 2006; Xu \& Chang, 2008). Additionally, studies have determined that growth location plays a role in the sugar profile of cashew nuts. Differences observed between the products analysed here could also be due to location effects. All of these reasons could explain the increase in the amount of monomers in the dry-roasted and wrapped cashew varieties (Rico et al., 2015).

\subsection{Vitamins and Minerals}

The cashews were analysed for the B-vitamins, thiamine (B1), riboflavin (B2), and niacin (B3), as well as tocopherols (Vitamin E), carotenoids (pro-vitamin A), and Vitamin K are reported in Table 7. Based on USDA standards, cashews were not good sources of any B-vitamins (USDA, 2015a; USDA, 2015c). The concentrations of B-vitamins in plants depend on variables such as processing, light, oxygen, and $\mathrm{pH}$. As seeds, nuts would only be required to begin metabolism during germination of the seedling, and thus would only require low levels of these compounds (Bartz \& Brecht, 2002).

Table 7. Vitamin Profile of Cashew Nuts

\begin{tabular}{llll}
\hline Vitamin & Raw & Dry-Roasted & Wrapped \\
\hline Thiamin $(\mathrm{mg} / 100 \mathrm{~g})$ & $0.042^{\mathrm{b}} \pm 0.003$ & $0.045^{\mathrm{ab}} \pm 0.001$ & $0.048^{\mathrm{a}} \pm 0.002$ \\
Riboflavin $(\mathrm{mg} / 100 \mathrm{~g})$ & $0.12^{\mathrm{b}} \pm 0.01$ & $0.13^{\mathrm{ab}} \pm 0.02$ & $0.18^{\mathrm{a}} \pm 0.04$ \\
Niacin $(\mathrm{mg} / 100 \mathrm{~g})$ & $0.34^{\mathrm{a}} \pm 0.19$ & $0.22^{\mathrm{a}} \pm 0.14$ & $0.58^{\mathrm{a}} \pm 0.20$ \\
Alpha Tocopherol $(\mu \mathrm{g} / \mathrm{g})$ & $1.92^{\mathrm{b}} \pm 0.3$ & $2.22^{\mathrm{b}} \pm 0.2$ & $4.25^{\mathrm{a}} \pm 0.3$ \\
Beta Tocopherol $(\mu \mathrm{g} / \mathrm{g})$ & $0.00^{\mathrm{a}} \pm 0.0$ & $0.00^{\mathrm{a}} \pm 0.0$ & $0.00^{\mathrm{a}} \pm 0.0$ \\
Gamma Tocopherol $(\mu \mathrm{g} / \mathrm{g})$ & $41.1^{\mathrm{b}} \pm 2.2$ & $40.7^{\mathrm{b}} \pm 0.5$ & $85.5^{\mathrm{a}} \pm 2.7$ \\
Delta Tocopherol $(\mu \mathrm{g} / \mathrm{g})^{\mathrm{a}}$ & $3.47^{\mathrm{a}} \pm 0.4$ & $2.76^{\mathrm{a}} \pm 0.9$ & $6.19^{\mathrm{a}} \pm 3.5$ \\
Total Tocopherols $(\mu \mathrm{g} / \mathrm{g})$ & $46.6^{\mathrm{b}} \pm 1.2$ & $45.9^{\mathrm{b}} \pm 1.4$ & $95.9^{\mathrm{a}} \pm 1.1$ \\
B-Carotene $(\mu \mathrm{g} / 100 \mathrm{~g})$ & $112.7^{2}$ & 113.8 & $352.8^{\mathrm{a}}$ \\
Vitamin K $(\mu \mathrm{g} / 100 \mathrm{~g})$ & $12.1^{\mathrm{a}} \pm 0.19$ & $12.7^{\mathrm{a}} \pm 0.06$ & $13.7^{\mathrm{a}} \pm 0.67$ \\
\hline
\end{tabular}

Different letters across rows signify significantly different values, $\mathrm{p}<0.05$.

Pairwise differences determined by Tukey's HSD

* Since variances were unequal, Wilcoxon's test with multiple comparisons was used.

The most abundant vitamin in the cashew nuts was vitamin $\mathrm{E}$, which serves to prevent oxidation of the unsaturated fatty acids found there (Delgado-Zamarreno, Bustamante-Rangel, Sanchez-Perez, \& Hernandez-Mendez, 2001). As in other nut types, $\gamma$-tocopherol was the prevalent isomer of vitamin $\mathrm{E}$ found in the cashews across samples. The $\gamma$ form of tocopherol has been found to be more potent at protecting against oxidation in the lipid storage components of plants (Abbasi, Hajirezaei, Hofius, Donnewald, \& Voll, 2007). In contrast, $\alpha$-tocopherol, the only tocopherol isomer considered to have biological activity in humans, is more active in metabolizing tissue and is therefore not as prevalent in the cashews (USDA, 2015b). The wrapped samples had higher amounts of $\alpha$ - and $\gamma$ - tocopherol compared to the other samples. It was hypothesized that the antioxidants in the cashew skins could be acting as a first line of defense against free radicals, thus sparing the $\gamma$-tocopherol within the nuts themselves (USDA-ARS, 2014).

The vitamin $\mathrm{K}$ content of the cashews in this study were consistent across sample types since heat processing has been reported to have no effect on vitamin $\mathrm{K}$ (Leskova et al., 2006). The vitamin K present in the nuts assists vitamin $\mathrm{E}$ in protecting lipids from oxidation (Asensi-Favado \& Munne-Bosch, 2010). Cashews, along with hazelnuts $(14.2 \mu \mathrm{g} / 100 \mathrm{~g})$ and pistachios $(13.2 \mu \mathrm{g} / 100 \mathrm{~g})$ have the highest levels of vitamin $\mathrm{K}$ across nut types (Dismore, Haytowitz, Gebhardt, Peterson, \& Booth, 2003).

Carotenoids were analysed in the samples and detected at low levels. Again, the wrapped nuts had more than double the amount found in the raw and dry roasted samples. Carotenoids are typically found in the skins of fruits and vegetables. This may hold true for cashew skins, however the amounts of carotenoids in the cashew skins were 100-fold less than the amounts found in fruit and vegetable skins. Cashew skins are not a significant source of carotenoids or provitamin A (Chen \& Blumberg, 2008; Bolling, Chen, McKay, \& Blumberg, 2011; Kornsteiner, Wagner, \& Elmadfa, 2006).

Table 8 lists the values determined for the major minerals analysed in the cashews. The mineral profile of any plant species is highly dependent upon the soil composition and very few differences were observed across 
samples in terms of the mineral profiles (Ekholm et al., 2007). The minerals present at high enough concentrations to warrant nutrition label claims were phosphorous, potassium, and magnesium, all which are required for cellular differentiation and proliferation of a germinating seedling (Fagbemi, 2008; Segura, Javierre, Lizarrage, \& Ros, 2006; USDA, 2015c). Additionally, the cashews contain some important trace minerals. Trace minerals are toxic when consumed in excess. The typical serving $(1 \mathrm{oz})$ of cashews would not approach toxic levels (Fraga, 2005). Cashew trees are typically grown in nutrient deficient, unfertilized, soil, resulting in the low levels of minerals found in the cashews in this study (Ekholm et al., 2007; Ibiremo, Ogunlade, Oyetunji, \& Adewale, 2012).

Table 8. Mineral Profile of Cashew Nuts

\begin{tabular}{llll}
\hline Mineral & Raw & Dry-Roasted & Wrapped \\
\hline Phosphorous (wt. \%) & $0.58^{\mathrm{a}} \pm 0.00$ & $0.60^{\mathrm{ab}} \pm 0.01$ & $0.50^{\mathrm{ab}} \pm 0.00$ \\
Potassium (wt. \%) & $0.73^{\mathrm{a}} \pm 0.02$ & $0.75^{\mathrm{a}} \pm 0.02$ & $0.75^{\mathrm{a}} \pm 0.00^{\mathrm{a}}$ \\
Calcium (wt. \%) & $0.04^{\mathrm{a}} \pm 0.00$ & $0.05^{\mathrm{b}} \pm 0.00$ & $0.06^{\mathrm{c}} \pm 0.00$ \\
Magnesium (wt. \%) & $0.28^{\mathrm{a}} \pm 0.00$ & $0.30^{\mathrm{a}} \pm 0.00$ & $0.25^{\mathrm{a}} \pm 0.01$ \\
Sodium (wt. \%) & $0.01^{\mathrm{a}} \pm 0.00$ & $0.30^{\mathrm{b}} \pm 0.00$ & $0.71^{\mathrm{c}} \pm 0.03$ \\
Iron (mg/kg)* & $70.6^{\mathrm{a}} \pm 0.05$ & $70.3^{\mathrm{a}} \pm 1.3$ & $78.9^{\mathrm{a}} \pm 1.1$ \\
Copper (mg/kg) & $21.8^{\mathrm{a}} \pm 0.06$ & $21.2^{\mathrm{a}} \pm 0.4$ & $19.63^{\mathrm{a}} \pm 0.4$ \\
Manganese (mg/kg) & $19.9^{\mathrm{a}} \pm 1.0$ & $20.8^{\mathrm{a}} \pm 0.2$ & $20.5^{\mathrm{a}} \pm 0.5$ \\
Zinc (mg/kg) & $67.8^{\mathrm{a}} \pm 1.0^{\mathrm{a}}$ & $70.2^{\mathrm{a}} \pm 1.0$ & $59.7^{\mathrm{b}} \pm 0.8$ \\
\hline
\end{tabular}

Different letters across rows signify significantly different values, $\mathrm{p}<0.05$.

Pairwise differences determined by Tukey's HSD

* Since variances were unequal, Wilcoxon's test with multiple comparisons was used.

\subsection{Phenolic Content and Bioactivity}

Multiple analyses were performed on the cashews to determine the presence and chemical activity of phenolic compounds present in the cashew samples and reported in Table 9. The total phenolic assay and the HPLC analyses indicated that the concentration of the phenolic compounds were significantly higher in the wrapped cashews than in the raw or roasted. This confirmed that the phenolics were predominantly present in cashew skins (Kamath and Rajini, 2007). The antioxidant character as measured by free radical scavenging ability of the samples was evaluated using the DPPH assay. The DDPH value in the extracts from the skin-on cashews was found to be 25 fold higher than in either the raw or the dry-roasted sample extracts (Table 9). Correspondingly, the ORAC scores were also higher in the skin-on samples. Although there is no link between ORAC scores and biological antioxidant activity, the scores for the wrapped nuts were similar to other antioxidant-containing compounds such as almonds (4454 $\mu \mathrm{g}$ TE/100g), blueberries $(4669 \mu \mathrm{g} \mathrm{TE} / 100 \mathrm{~g})$, sweet cherries $(3747 \mu \mathrm{g}$ TE/100g), and Granny Smith apples (3898 $\mu \mathrm{g}$ TE/100g) (USDA-ARS, 2010).

Table 9. Phenolic Analyses of Cashew Nuts

\begin{tabular}{llll}
\hline Analysis & Raw & Dry-Roasted & Wrapped \\
\hline Folin-Ciocalteu (mg GAE/100g) & $81.6^{\mathrm{b}} \pm 14.1$ & $95.4^{\mathrm{b}} \pm 16.6$ & $301.0^{\mathrm{a}} \pm 28.0$ \\
DPPH (mg TE/g) & $1.05^{\mathrm{b}} \pm 0.16$ & $1.07^{\mathrm{b}} \pm 0.11$ & $25.2^{\mathrm{a}} \pm 0.74$ \\
ORAC ( $\mu \mathrm{g}$ TE/100g) & $711.4^{\mathrm{b}} \pm 83.0$ & $599.5^{\mathrm{b}} \pm 55.3$ & $4287.9^{\mathrm{a}} \pm 350.5$ \\
Procyanidins as Trimers (mg/100g) & $136.6^{\mathrm{b}} \pm 11.7$ & $28.0^{\mathrm{b}} \pm 21.3$ & $1473.5^{\mathrm{a}} \pm \mathrm{NA}$ \\
Small Molecule Phenolics as Epicatechin $(\mu \mathrm{g} / \mathrm{g})$ & $540.9^{\mathrm{b}} \pm 107.2$ & $398.3^{\mathrm{b}} \pm 148.9$ & $1567.3^{\mathrm{a}} \pm \mathrm{NA}$ \\
\hline
\end{tabular}

Different letters across rows signify significantly different values, $\mathrm{p}<0.05$.

Pairwise differences determined by Tukey's HSD

* Since variances were unequal, Wilcoxon's test with multiple comparisons was used.

When quantifying the procyanidins in the cashews using HPLC on a whole nut basis, it was noted that compounds exhibiting greater than 3 degrees of polymerization (DP3) were essentially nonexistent in the samples. Other nut skins including peanuts contain monomers, oligomers, and polymer phenolic compounds (Monagas et al., 2009). Given these observations, the data suggests that the water washing technique, necessary 
to remove the CNSL, could also be removing larger phenolics and tannins in the process. In order to test this hypothesis, it would be worth investigating the phenolic profile of nut skins that have not been washed. An alternative CNSL removal method that does not remove the larger water-soluble phenolic compounds would be needed (Constanza et al., 2012; Nair, 2003).

\subsection{CNSL content}

The novel wrapped cashew nuts were washed with a patented water washing technique to remove the CNSL from the skins to allow for safe consumption of cashew skins, thus benefiting from the antioxidants present (Nair, 2003). As such, the novel cashews products in this study were analysed for residue CNSL to ensure proper removal (Table 10). CNSL was detected at the parts per million level, indicating that they were thoroughly cleaned by the water washing method.

Table 10. Residue CNSL in Cashew Nuts

\begin{tabular}{llll}
\hline & Raw & Dry-Roasted & Wrapped \\
\hline CNSL $(\mu \mathrm{g} / \mathrm{g})$ & $0.023^{\mathrm{a}} \pm 0.04$ & $0.032^{\mathrm{a}} \pm 0.03$ & $1.07^{\mathrm{b}} \pm 0.14$ \\
\hline
\end{tabular}

Different letters across rows signify significantly different values, $\mathrm{p}<0.05$.

Pairwise differences determined by Tukey's HSD

\section{Conclusions}

In summary, a nutritional characterization of raw, dry-roasted, and wrapped cashews was conducted. From this study, it is noted that the roasting processes had some effect on moisture, protein, phospholipids, sugars, and certain minerals. All the types of the cashews were found to contain bioactive compounds including oleic acid, linoleic acid, phytosterols, arginine, tocopherols, magnesium, and phenolic compounds. Of the three varieties, the wrapped nuts had the highest concentrations of phenolics and tocopherols, due to the presence of the skins. The concentrations of phytosterols in all of the cashew varieties were higher than reported values for other nuts. Additionally, the cashews were poor nutritional sources of B-vitamins, but had concentrations of phosphorous, magnesium, and potassium that could meet requirements for nutrition labelling. Future studies should examine the in-vivo effects of consuming cashew skin phenolics and if the cleaning step to remove CSNL involving water washes away phenolic compounds with higher DP.

\section{Conflict of Interest}

The authors declare no conflict of interest.

\section{Acknowledgements}

The authors would like to thank Dr. Ganesh Nair of Wenders Foods Inc. for supplying the cashews for this study.

\section{References}

Abbasi, A. R., Hajirezaei, M., Hofius, D., Sonnewald, U., \& Voll, L. M. (2007). Specific roles of alpha- and gamma-tocopherol in abiotic stress responses of transgenic tobacco. Plant Physiology, 143, 1720-1738. https://doi.org/10.1104/pp.106.094771

Akinhanmi, T., Atasie, V., \& Akintokun, P. (2008). Chemical composition and physiochemical properties of cashew nut (Anacardium occidentale) oil and cashew nut shell liquid. Journal of Agricultural, Food, and Environmental Sciences, 2, 1-10.

Asensi-Fabado, M. A., \& Munne-Bosch, S. (2010). Vitamins in plants: occurrence, biosynthesis and antioxidant function. Trends in Plant Science, 15, 582-592. https://doi.org/10.1016/j.tplants.2010.07.003

Assuncao, R. B., \& Mercadante, A. Z. (2003). Carotenoids and ascorbic acid from cashew apple (Anacardium occidentale L.): variety and geographic effects. Food Chemistry, 81, 495-502. http://dx.doi.org/10.1016/S0308-8146(02)00477-6

Azam-Ali, S., \& Judge, E. (2001). Small-scale cashew nut processing. Sri Lanka: FAO. http://www.fao.org/ag/ags/agsi/Cashew/Cashew.htm

Bannon, C. D., Craske, J. D., Hai, N. T., Hai, N. L., Happer, N. L., \& O’Rourke, K. L. (1982). Analysis of fatty acid methyl esters with high accuracy and reliability: II. Methylation of fats and oils with boron trifluoride-methanol. Journal of Chromatography A, 24, 63-69.

http://dx.doi.org/10.1016/S0021-9673(00)84856-6 
Bartz, J. A., \& Brecht, J. K. (2002). Postharvest physiology and pathology of vegetables. Gainesville, FL, USA: CRC Press. https://doi.org/10.1201/9780203910092

Bolling, B. W., Chen, C.-Y. O., McKay, D. L., \& Blumberg, J. B. (2011). Tree nut phytochemicals: composition, antioxidant capacity, bioactivity, impact factors. A systematic review of almonds, Brazils, cashews, hazelnuts, macadamias, pecans, pine nuts, pistachios, and walnuts. Nutrition Research Reviews, 24, 244-275. https://doi.org/10.1017/S095442241100014X

Brufau, G., Boatella, J., \& Rafecas, M. (2006). Nuts: Source of energy and macronutrients. British Journal of Nutrition, 16(S2), S24-S28. https://doi.org/10.1017/BJN20061860

Buchner, N., Krumbein, A., Rohn, S., \& Kroh, L. W. (2006). Effect of thermal processing on the flavonols rutin and quercetin. Rapid Communications in Mass Spectrometry, 20, 3229-3235. https://doi.org/10.1002/rcm.2720

Chen, C-Y. O., \& Blumberg, J. B. (2008). Phytochemical composition of nuts. Asian Pacific Journal of Clinical Nutrition, 17, 329-332. http://apjcn.nhri.org.tw/server/APJCN/17\%20Suppl\%201//329.pdf

Constanza, K. E, White, B. L, Davis, J. P., Sanders, T. H., \& Dean, L. L. (2012). Value-added processing of peanut skins: Antioxidant capacity, total phenolics, and procyanidin content of spray-dried extracts. Journal of Agricultural and Food Chemistry, 60, 10776-10783. http://dx.doi.org/10.1021/jf3035258

Davis, J., \& Dean, L. (2016). Peanut composition, flavor, and nutrition. In H. T. Stalker, \& R. F. Wilson (Eds.), Peanuts: Genetics, processing and utilization (pp. 289-345). San Diego, CA, USA: Elsevier.

Delgado-Zamarreno, M. M., Bustamante-Rangel, M., Sanchez-Perez, A., \& Hernandez-Mendez, J. (2001). Analysis of vitamin $\mathrm{E}$ isomers in seeds and nuts with and without coupled hydrolysis by liquid chromatography and coulometric detection. Journal of Chromatography A, 935, 77-86. https://doi.org/10.1016/j.foodchem.2014.02.008

Dismore, M.L., Haytowitz, D. B., Gebhardt, S. E., Peterson, J. W., \& Booth, S. L. (2003). Vitamin K content of nuts and fruits in the US diet. Research and Professional Briefs, 103, 1650-1652. https://doi.org/10.1016/j.jada.2003.09.028

Donato, P., Cacciola, F., Cichello, F., Russo, M., Dugo, P., \& Mondello, L. (2011). Determination of phospholipids in milk samples by means of hydrophilic interaction liquid chromatography coupled to evaporative light scattering and mass spectrometry detection. Journal of Chromatography A, 1218, 6476-6482. https://doi: 10.1016/j.chroma.2011.07.036

Ekholm, P., Reinivuo, H., Mattila, P., Pakkala, H., Koponen, J., Happonen, A., Hellstrom, H., \& Ovaskainen, M. J. (2007). Changes in the mineral and trace element contents of cereals, fruits and vegetables in Finland. Journal of Food Composition and Analysis, 20, 487-495. https://doi: 10.1016/j.jfca.2007.02.007

Fagbemi, T. N. (2008). The influence of processing techniques on the energy, ash properties and elemental composition of cashew nut (Anacardium occidentale). Nutrition \& Food Science, 38, 136-145. https://doi.org/10.1108/00346650810863019

Firestone, D. (Ed.) (2004). Official methods and recommended practices of the American Oil Chemists Society (5th ed). Champaign, IL, USA: American Oil Chemists Society.

Food and Drug Administration. (2013). Nuts and nut products methods. Retrieved October 15, 2014 from: http://www.fda.gov/food/foodscienceresearch/laboratorymethods/ucm084406.htm

Fraga, C. G. (2005). Relevance, essentiality and toxicity of trace elements in human health. Molecular Aspects of Medicine, 26,235-244. https://doi.org/10.1016/j.mam.2005.07.013

Gedam, P., \& Sampathkumaran, P. (1986). Cashew nut shell liquid: extraction, chemistry, and applications. Progress in Organic Coatings, 14, 115-157. https://doi.org/10.1016/0033-0655(86)80009-7

Hagen, S.R., Frost, B., \& Augustin, J. (1989). Precolumn phenylisothiocyanate derivatization and liquid chromatography of amino acids in foods. Journal of the Association of Official Analytical Chemists, 72, 912-916.

Hashim, I. B., Koehler, P. E., Eitenmiller, R. R., \& Kvien, C. K. (1993). Fatty acid composition and tocopherols content of drought stressed florunner peanuts. Peanut Science, 20, 21-24. https://doi.org/10.3146/i0095-3679-20-1-6

Hebbar, U. H., \& Ramesh, M. (2005). Optimization of processing conditions for infrared drying of cashew 
kernels with testa. Journal of the Science of Food and Agriculture, 85, 865-871. https://doi/10.1002/jsfa.2045

Ibiremo, O. S., Ogunlade, M. O., Oyetunji, O. J., \& Adewale, B. D. (2012). Dry matter yield and nutrient uptake of cashew seedlings as influenced by arbuscular mycorrhizal inoculation, organic and inorganic fertilizers in two soils in Nigeria. Journal of Agricultural and Biological Science, 7, 196-205.

Kamath, V., \& Rajini, P. (2007). The efficacy of cashew nut (Anacardium occidentale L.) skin extract as a free radical scavenger. Food Chemistry, 103, 428-433. https://doi.org/10.1016/j.foodchem.2006.07.031

King, J. C., Blumberg, J., Ingwersen, L., Jenab, M., \& Tucker, K. L. (2008). Tree nuts and peanuts as components of a healthy diet. The Journal of Nutrition, 138, 1736S-1740S.

Kornsteiner, M., Wagner, K.-H, \& Elmadfa, I. (2006). Tocopherols and total phenolics in 10 different nut types. Food Chemistry, 98, 381-387. http://dx.doi.org/10.1016/j.foodchem.2005.07.033

Kris-Etherton, P. M., Hu, F. B., Rose, E., \& Sabate, J. (2008). The role of tree nuts and peanuts in the prevention of coronary heart disease: Multiple potential mechanisms. The Journal of Nutrition, 138, 1746S-1751S.

Kuminek, G., Stulzer, H. K., Tagliari, M. P., Oliveira, P. R., Bernardi, L. S., Rauber, G. S., \& Cardoso, S. G. (2011). High-performance column liquid chromatographic method for the simultaneous determination of buclizine, tryptophan, pyridoxine, and cyanocobalamin in tablets and oral suspension. Journal of the AOAC International, 94, 1785-1790. https://doi.org/10.5740/jaoacint.10-207

Latimer, Jr., G.W. (Ed.) (2012). Official methods of analysis of the Association of Official Analytical Chemists. Rockville, MD, USA: AOAC International.

Lee, J., Welti, R., Schapaugh, W. T., \& Trick, H. N. (2011). Phospholipid and triacylglycerol profiles modified by PLD suppression in soybean seed. Plant Biotechnology Journal, 9, 359-372. https://doi.org/10.1111/j.1467-7652.2010.00562.x

Leskova, E., Kubikova, J., Kovacikova, E., Kosicka, M., Porubska, J., \& Hocikova, K. (2006). Vitamin losses: Retention during heat treatment and continual changes expressed by mathematical models. Journal of Food Composition and Analysis, 19, 252-276 https://doi:10.1016/j.jfca.2005.04.014

Lim, T. (2012). Edible medicinal and non-medicinal plants. New York, NY, USA: Springer.

Luh, B. S, Wong, W. S, \& El-Shimi, N. E. (1981). Effect of processing on some chemical constituents of pistachio nuts. Journal of Food Quality, 5, 33-41. https://doi: 10.1081/DRT-120021688

Maguire, L.S., O'Sullivan, S.M., Galvin, K., O'Connor, T.P, \& O’Brien, N.M. (2004). Fatty acid profile, tocopherols, squalene and phytosterol content of walnuts, almonds, peanuts, hazelnuts, and the macadamia nut. International Journal of Food Sciences and Nutrition, 55, 171-178. https://doi.org/10.1080/09637480410001725175

Maia, J. G. S., Andrade, E. H. A., \& Zoghbi, M. D. G. B. (2000). Volatile constituents of the leaves, fruits, and flowers of cashew (Anacardium occidentale L.). Journal of Food Composition and Analysis, 13, 227-232. https://doi.org/10.1006/jfca.2000.0894

Martin, P. J., Topper, C. P., Bashiru, R. A., Boma, F., De Wall, D., Harries, H. C., ... Stathers, T. (1997). Cashew nut production in Tanzania: Constraints and progress through integrated crop management. Crop Protection, 16, 5-14. https://doi: 10.1016/S0261-2194(96)00067-1

Monagas, M., Rybarecyzyk, A., Amarowicz, R., Bartolome, B., Ignacio, G., Lebron-Aguilar, R., \& Gomez-Cordoves, M.C. (2009). Comparative flavan-3-ol profiles and antioxidant capacity of roasted peanuts. Journal of Agricultural and Food Chemistry, 57, 10590-10599. https://doi.org/10.1021/jf901391a

Moreno, M., Olivares, M., Lopez, A., Adelantado, G., \& Reig, B. (1999). Analytical evaluation of polyunsaturated fatty acids degradation during thermal oxidation of edible oils by Fourier Transform Infrared Spectroscopy. Talanta, 50, 267-275. https://doi.org/10.1016/S0039-9140(99)00034-X

Nair, H. (2003). US Patent No. US20050089613 A1. Washington, DC: U.S. Patent and Trademark Office.

Otles, S., \& Cagindi, O. (2007). Determination of vitamin $\mathrm{K}_{1}$ content in olive oil, chard, and human plasma by RP-HPLC method with UV-Vis detection. Food Chemistry, 100, 1220-1222. https://doi:10.1016/j.foodchem.2005.12.003

Paramashivappa, R., Kumar, P.P., Vithayathil, P.J., \& Rao, A.S. (2001). Novel method for isolation of major phenolic constituents from cashew (Anacardium occidentale L.) nut shell liquid. Journal of Agricultural 
and Food Chemistry, 49, 2548-2551. https://doi.10.1021/jf001222j

Pattee, H. E., Isleib, T. G., Giesbrecht, F. G., \& McFeeters, R. F. (2000). Investigations in genotypic variations of peanut carbohydrates. Journal of Agricultural and Food Chemistry, 48, 750-756. https://doi.10.1021/jf9910739

Phillips, K. M., Ruggio, D. M., \& Ashraf-Khorassani, M. (2005). Phytosterol composition of nuts and seeds commonly consumed in the United States. Journal of Agricultural and Food Chemistry, 53, 9436-9445. https://doi.10.1021/jf051505h

Piironen, V., \& Koivu, T. (2000). Quality of vitamin K analysis and food composition data in Finland. Food Chemistry, 68, 223-226. https://doi.org/10.1016/S0308-8146(99)00159-4

Piironen, V., Lindsay, D. G., Miettinen, T. A., Toivo, J., \& Lampi, A. M. (2000). Plant sterols: Biosynthesis, biological function and their importance to human nutrition. Journal of the Science of Food and Agriculture, 80, 939-966. https://doi.org/10.1016/S0308-8146(99)00159-4

Plank, D. W., Szpylka, J., Sapirstein, H., Woollard, D., Zapf, C. M., Lee, V., Chen, C-Y. O, Liu, R. H, Tsao, R., Dusterloh, An., \& Baugh, S. (2012). Determination of antioxidant activity in foods and beverages by reaction with 2,2'-Diphenyl-1-Picrylhydrzyl, (DPPH): Collaborative study first action 2012.04. Journal of the AOAC International, 95, 1562-1569. https://doi.org/10.5740/jaoacint.CS2012_04

Rein, M. J., Renouf, M., Cruz-Hernandez, C., Actis-Goretta, L., Thakkar, S. K., \& da Silva Pinta, M. (2013). Bioavailability of bioactive food compounds. A challenging journey to bioefficacy. British Journal of Clinical Pharmacology, 75, 588-602. https://10.1111/j.1365-2125.2012.04425.x

Rico, R., Bullo, M., \& Salas-Salvado, J. (2015). Nutritional composition of raw fresh cashew (Anacardium occidentale L.) kernels from different origin. Food Science \& Nutrition, 4, 329-338. https://doi.10.1002/fsn3.294

Ryan, E., Galvin, K., O’Connor, T. P., Maguire, A. R., \& O’Brien, N. M. (2006). Fatty acid profile, tocopherol, squalene and phytosterol content of Brazil, pecan, pine, pistachio and cashew nuts. International Journal of Food Sciences and Nutrition, 57, 219-228. http://dx.doi.org/10.1080/09637480600768077

Salam, M. A., \& Peter, K.V. (2010). Cashew - A monograph. New Delhi, India: Studium Press Pvt. Ltd.

Segura, R., Javierre, C., Lizarraga, M.A., \& Ros, E. (2006). Other relevant components of nuts: Phytosterols, folate and minerals. British Journal of Nutrition, 96; 536-544. https://doi.org/10.1017/BJN20061862

Shi, H.-T., \& Chan, Z.-L. (2013). In vivo role of Arabidopsis arginase in arginine metabolism and abiotic stress response. Plant Signaling and Behavior, 8, e245138. http://dx.doi.org/10.4161/psb.24138

Singleton, V. L., Orthofer, R., \& Lamuela-Raventos, R. M. (1999). Analysis of total phenols and other oxidation substrates and antioxidants by means of Folin-Ciocalteau reagent. In Methods in Enzymology Polyphenols and Flavonoids. Sies, H., et al. (eds.), 152-178. Academic Press, San Diego. https://doi.org/10.1016/S0076-6879(99)99017-1

Teuber, S. S., Sathe, S. K., Peterson, W. R., \& Roux, K. H. (2002). Characterization of the soluble allergenic proteins of cashew nut (Anacardium occidentale L.). Journal of Agricultural and Food Chemistry, 50, 6543-6549. https://doi.10.1021/jf025757j

Trox, J., Vadivel V., Vetter, W., Stuetz, W., Scherbaum, V., Gola, U., Nohr, D., \& Biesalski, H. K. (2010). Bioactive compounds in cashew nut (Anacardium occidentale L.) kernels: Effect of different shelling methods. Journal of Agricultural and Food Chemistry, 58, 5341-5346. https://doi.10.1021/jf904580k

United States Department of Agriculture, Agricultural Research Service. (2010). Oxygen Radical Absorbance Capacity (ORAC) of Selected Foods, Release 2 (2010). Retrieved January 30, 2016 from: http://www.ars.usda.gov/Services/docs.htm?docid=15866

United States Department of Agriculture, Agricultural Research Service. (2014). National Nutrient Database for Standard Reference Release 28. Retrieved February 2, 2016 from: http://ndb.nal.usda.gov/ndb/foods

United States Department of Agriculture. (2015a). Dietary Reference Intakes for Thiamin, Riboflavin, Niacin, Vitamin B6, Vitamin B12, Pantothenic Acid, Biotin, and Choline. Retrieved September 23, 2015 from: https://fnic.nal.usda.gov/dietary-guidance/dri-nutrient-reports/thiamin-riboflavin-niacin-vitamin-b6-folate-v itamin-b12

United States Department of Agriculture. (2015b). Dietary Reference Intakes for Vitamin C, Vitamin E, 
Selenium, and Carotenoids. Retrieved September 23, 2015 from:

https://fnic.nal.usda.gov/dietary-guidance/dri-nutrient-reports/vitamin-c-vitamin-e-selenium-and-carotenoids

United States Department of Agriculture. (2015c). DRI Tables and Application Reports. Retrieved September 23, 2015 from: https://fnic.nal.usda.gov/dietary-guidance/dietary-reference-intakes/dri-tables-and-application-reports

Venkatachalam, M., \& Sathe, S. K. (2006). Chemical composition of selected edible nut seeds. Journal of Agricultural and Food Chemistry, 54, 4705-4714. https://doi.10.1021/jf0606959

Wall, M. M., \& Gentry, T. S. (2007). Carbohydrate composition and color development during drying and roasting of macadamia nuts (Macadamia integrifolia). LWT, 40, 587-593. https://doi.org/10.1016/j.lwt.2006.03.015

Winkler, J. K., Warner, K., \& Glynn, M. T. (2007). Effect of deep-fat frying on phytosterol content in oils with differing fatty acid composition. Journal of American Oil Chemical Society, 84, 1023-1030. https://doi.org/10.1007/s11746-007-1138-1

Xu, B., \& Chang, S. K. C. (2008). Total phenolics, phenolic acids, isoflavones, and anthocyanins and antioxidant properties of yellow and black soybeans as affected by thermal processing. Journal of Agricultural and Food Chemistry, 56, 7165-7175. https://doi.10.1021/jf8012234

Xue, H.-W., Chen, X., \& Mei, Y. (2009). Function and regulation of phospholipid signaling in plants. Biochemical Journal, 421, 145-156. https://doi.10.1042/BJ20090300

Young, J. H., Whitaker, T. B., Blankenship, P. D., Brusewitz, G. H., Troeger, J. M., Steele, J. L., \& Person Jr., N. K. (1982). Effect of oven drying time on peanut moisture determination. Transactions of the ASAE, 25, 491-495. https://doi.10.13031/2013.33560

\section{Copyrights}

Copyright for this article is retained by the author(s), with first publication rights granted to the journal.

This is an open-access article distributed under the terms and conditions of the Creative Commons Attribution license (http://creativecommons.org/licenses/by/4.0/). 